\title{
Surgical Outcomes and Early Postoperative Complications in Locally Advanced Gastric Cancer
}

\section{Lokal İleri Evre Mide Kanserinde Cerrahi Sonuçlar ve Erken Postoperatif Komplikasyonlar}

\author{
Lütfi Doğan ${ }^{1}$, Niyazi Karaman ${ }^{1}$, Sevinç Hüseyinova ${ }^{2}$,Cihangir Özaslan ${ }^{1}$, \\ ${ }^{1}$ Dr. A. Y. Ankara Oncology Training and Research Hospital, General Surgery Department \\ ${ }^{2}$ Uşak State Hospital, General Surgery
}

DOI: $10.5505 /$ aot.2011.29392

\section{ÖZET}

Amaç: Batı ülkelerinde saptanan mide kanserlerinin \%60-65'i tanı anında lokal ileri evrededirler. Bu hastalara uygulanan genişletilmiş rezeksiyonlar komplikasyon riskini arttırabilir. Bu çalışmanın amacı lokal ileri evre mide kanserlerinde rezektabilite, erken dönem mortalite ve morbidite oranlarını saptamaktır.

Hastalar ve Yöntem: Ocak 2002 ile Eylül 2006 tarihleri arasında rezeksiyon uygulanan non-metastatik, lokal ileri evre mide kanserli hastalarımız geriye dönük olarak incelendi.

Bulgular: Komşu organ invazyonu nedeni ile 110 hastaya $(\% 49.8)$ ek organ rezeksiyonu uygulanmıştı. Yüz seksen bir hastaya (\%82) R0, 29 hastaya (\%13) R1 ve 11 hastaya (\%5) R2 rezeksiyon yapılabilmişti. Tüm serinin morbidite ve mortalite oranları sirasıyla $\% 21.7$ ve $\% 4.5$ olarak bulundu. İkiden fazla ek organ rezeksiyonu $(p=0.001), 2$ üniteden fazla kan transfüzyonu $(p=0.001)$ ve düşük protein seviyeleri $(p=0.008)$ multivaryant analizlerde komplikasyon oranlarını arttıran parametreler olarak saptandı. İki veya daha fazla ek organ rezeksiyonu $(\mathrm{p}=0.001)$, kardiyovasküler ve respiratuar komorbidite $(\mathrm{p}=0.002)$ ve total gastrektomi uygulanması $(\mathrm{p}=0.028)$ mortaliteyi arttıran faktörler olarak bulundu.

Sonuç: Neo-adjuvan tedavi uygulanmayan lokal ileri evre mide kanserli hastalarda ek organ rezeksiyonu oranları yüksektir ve bu durum morbidite ve mortalite oranlarını arttırır. Total gastrektomi mortaliteyi arttıran bir faktör olarak belirlenmiş ancak D2 diseksiyonun bu hastalarda güvenle uygulanabileceği sonucuna varılmıştır.

Anahtar kelimeler: Komplikasyon; Lokal ileri evre mide kanseri; Morbidite; Mortalite

\begin{abstract}
Objective: In Western world, 60 to $65 \%$ of the gastric cancer cases are in locally advanced stage at the time of diagnosis. Extended resections may increase the risk of complications in these patients. The aim of this study was to investigate the resectability, early morbidity and mortality rates for locally advanced gastric cancer.

Patients and Methods: Non-metastatic locally advanced gastric cancer patients who underwent resection between January 2002 and September 2006 were analyzed retrospectively.

Results: One hundred and ten patients (49.8\%) had additional organ resection due to adjacent organ involvement. R0 resection was performed in 181 patients (82\%), R1 resection in 29 patients (13\%), and R2 resection in 11 patients (5\%). The morbidity and mortality rates of the all series were $21.7 \%$ and $4.5 \%$ respectively. According to multivariate analysis more than two additional organ resections ( $p=0.001)$, erythrocyte transfusions of more than 2 units $(\mathrm{p}=0.001)$ and low total protein levels $(\mathrm{p}=0.008)$ were determined as the parameters that increase complication rates. The parameters that increase mortality rates were as follows; having two or more additional organ resections $(\mathrm{p}=0.001)$, cardiovascular and respiratory comorbidities $(\mathrm{p}=0.002)$ and total gastrectomy $(\mathrm{p}=0.028)$.

Conclusion: Additional organ resection rate of the patients with locally advanced gastric cancers that not given neo-adjuvant treatment is high and this occurrence increases the morbidity and mortality rates. Although total gastrectomy has been found to be a factor for increased mortality in locally advanced gastric cancer, D2 dissection is safe for these patients
\end{abstract}

Key words: Complications; Locally advanced gastric cancer; Morbidity; Mortality

\section{Introduction}

Gastric cancer is a common aggressive tumor. According to WHO registrations approxima- tely 900.000 patients have gastric cancer that constitutes $10 \%$ of all cancer patients (1).

Surgery is the only curative treatment modality for gastric cancer. Curative surgery is the resection of stomach and all metastatic 
lymph nodes with negative surgical margins in patients with no peritoneal or distant metastases. The aim of surgery in gastric cancer is to increase the quality of life and overall survival. It was reported that more than $50 \%$ of patients have distant metastases at the time of diagnosis of gastric cancer (2). Curative resection is possible only in $30-50 \%$ of the patients. The rate of regional lymph node metastases was reported as $70-80 \%$ in resectable patients (3). In Western world, 60 to $65 \%$ of the gastric cancer cases are in locally advanced stage (stage IIIA, IIIB and IV) at the time of diagnosis and in these patients, extended resections may increase the risk of complications (4).

The aim of this study was to investigate the resectability rates and to determine early morbidity and mortality rates after resections for locally advanced gastric cancer.

\section{Patients and methods}

Consecutive non-metastatic locally advanced gastric cancer patients treated between October 2002 and September 2006 at Dr. A. Y. Ankara Oncology Training and Research Hospital were included in this retrospective exploratory analytical study. All patients had gastrectomy. They were evaluated in terms of age, gender, total protein, albumin and hemoglobin levels, comorbidities, erythrocyte transfusions, tumor localization, operation types, dissection, additional organ resection, number of resected lymph nodes and metastatic lymph nodes, tumor differentiation, resection margins, complications and mortality rates in postoperative 30 days. Patients with peritoneal carcinomatosis were excluded and none of the patients in this series had received neoadjuvant treatment.

Diabetes mellitus, hypertension, chronic obstructive pulmonary disease and cardiovascular diseases were defined as comorbid conditions. Total or subtotal gastrectomies either with or without D2 dissections were evaluated separately. Additional organ resections were grouped as none, one, two, three or more. Organ resections such as colon, liver, spleen, pancreas, small intestine and diaphragm were taken into consideration. TNM staging by American Joint Committee on Cancer
Classification was used. Any complication that occurred in postoperative 30 days was defined as early morbidity. Total protein measurement less than $5 \mathrm{gr} / \mathrm{dL}$, albumin less than $2.5 \mathrm{gr} / \mathrm{dL}$, hemoglobin less than $10 \mathrm{gr} / \mathrm{dL}$ and lymphocyte count less than $900 / \mathrm{mL}$ were accepted as the lowest limits. Cardiac complications were defined as arrhythmia and myocardial infarction as evidenced by electrocardiographic changes and elevated cardiac enzymes, whereas pulmonary complications were atelectasia or pneumonia confirmed clinically, by sputum culture or chest X-ray. Anastomotic leakage documented with radiologic studies, fistulas with drainage of $50 \mathrm{ml} /$ day or more than 5 days in postoperative period, pulmonary thromboembolism proven with ventilation and perfusion scintigraphy and/or CT angiography, urinary or wound infections confirmed by cultures were also recorded. R0 resection was defined as the complete removal of the tumor with negative microscopic resection margins either with or without additional organ resection. Deaths within postoperative 30 days of hospitalization were defined as postoperative mortality.

\section{Statistical Evaluation}

The groups formed for the evaluation of complications and mortality were analyzed with SPSS 10.00 statistical software. Comparison of the groups was evaluated with chi-square test. All $\mathrm{p}$ values were considered significant if less than 0.05. Logistic regression test was used for multivariate analysis.

\section{Results}

Two hundred and twenty-one gastric cancer patients with a mean age of 57.7 years (range 28-83) were included in the study. One hundred and forty-three of the patients were male and 78 were female. Number of patients treated with total and subtotal gastrectomy was $124(61.9 \%)$ and 97 (38.1\%), respectively. One hundred and fourty-seven $(66.5 \%)$ patients had D2 dissection, whereas $74(33.5 \%)$ had D1 dissection. One hundred and ten patients $(49.8 \%)$ had additional organ resection due to adjacent organ involvement; 36.2 percent of these patients $(n=80)$ had one, 11.3\% $(n=25)$ had two and $2.3 \%(n=5)$ had three or more organ resections. Eighty-seven had splenectomy, 32 had distal pancreatic-tomy, 6 
had resections of small intestine, 13 had resections of colon, 8 had hepatic and one had diaphragmatic resections. Sixty-five of the patients in one additional organ resection group had splenectomy. R0 resection was achieved in 181 patients (82\%), R1 resection in 29 patients (13\%), and $\mathrm{R} 2$ resection in 11 patients (5\%). The numbers of lymph nodes retrieved with D1 and D2 dissections were 14.3 (5-29) and 30.0 (18-58), respectively (p:0.02). The median numbers of involved lymph nodes were 7 (0-20) in D1 dissection and $8.9(0-45)$ in $\mathrm{D} 2$ dissection.

Demographic characteristics of the patients were shown in Table 1 and operational features and pathological findings were shown in Table 2 , respectively. The morbidity and mortality rates of the all series were $21.7 \%$ and $4.5 \%$ respectively. Complications according to gastrectomy, dissection and additional organ resection type were shown in Table 3.

Table 1. Demographic characteristics of the patients

\begin{tabular}{|l|l|c|}
\hline \multicolumn{2}{|l|}{ Characteristic } & \multicolumn{2}{|c|}{$\mathrm{n}(\%)$} \\
\hline \multirow{4}{*}{ Age } & $>50$ & $47(21.3)$ \\
& $>50$ & $174(78.7)$ \\
& Male & $143(64.7)$ \\
Total protein level & Female & $78(35.3)$ \\
Hemoglobin & Normal & $128(57.9)$ \\
Lymphocyte & Low $(<5 \mathrm{gr} / \mathrm{dL})$ & $93(42.1)$ \\
Cardiac Comorbidities & Low $(<10 \mathrm{gr} / \mathrm{dL})$ & $123(55.7)$ \\
Respiratory Comorbidities & Low $(<900 / \mathrm{mL})$ & $47(21.3)$ \\
Diabetes Mellitus & & $28(12.7)$ \\
Pre-operative transfusion & & $7(5.9)$ \\
Post-operative transfusion & & $28(12.7)$ \\
\hline
\end{tabular}

Table 3. Complications in relation to the procedures

\begin{tabular}{|lcccccc|}
\hline & Gastrectomy type & Dissection type & Additonal Organ Resection \\
& Distal & Total & D1 & D2 & $(-)$ & $(+)$ \\
\hline Respiratory & 4 & 20 & 8 & 16 & 7 & 17 \\
\hline Cardiac & 5 & 8 & 6 & 7 & 4 & 9 \\
\hline Cranial embolus & 1 & 1 & 1 & 1 & 1 & 1 \\
\hline Fistula & 9 & 22 & 11 & 20 & 8 & 23 \\
\hline Wound infection & 2 & 2 & 2 & 2 & 2 & 2 \\
\hline Dehiscence & 1 & 2 & 0 & 3 & 1 & 2 \\
\hline Intraabdominal Abcess & 2 & 6 & 1 & 7 & 2 & 6 \\
\hline Intraabdominal Hemorrhage & 1 & 2 & 1 & 2 & 1 & 2 \\
\hline
\end{tabular}


Table 2. Surgical features and pathological findings

\begin{tabular}{|c|c|c|}
\hline Feature & & $\mathrm{n}(\%)$ \\
\hline \multirow{4}{*}{ Tumor Localization } & Proximal & $52(23.5)$ \\
\hline & Distal & $93(42.1)$ \\
\hline & Corpus & $48(21.7)$ \\
\hline & Diffuse & $28(12.7)$ \\
\hline \multirow[t]{2}{*}{ Dissection type } & D1 & $74(33.3)$ \\
\hline & D2 & 147 (66.7) \\
\hline \multirow{2}{*}{ Gastrectomy type } & Total & $124(61.9)$ \\
\hline & Subtotal & $97(38.1)$ \\
\hline \multirow[t]{4}{*}{ Additional organ resection; } & 0 & $111(50)$ \\
\hline & 1 & $80(36)$ \\
\hline & 2 & $25(11.3)$ \\
\hline & 3 and more & $5(2.2)$ \\
\hline \multirow[t]{3}{*}{ Resection type } & R0 & $181(82)$ \\
\hline & $\mathrm{R} 1$ & $29(13)$ \\
\hline & $\mathrm{R} 2$ & $11(5)$ \\
\hline \multirow[t]{4}{*}{ Differentiation of the tumor } & Well & $39(17.6)$ \\
\hline & Moderate & $63(28.5)$ \\
\hline & Poor & $108(48.9)$ \\
\hline & Unknown & $11(5)$ \\
\hline \multirow[t]{2}{*}{ Number of resected lymph nodes } & $<20$ & $106(48)$ \\
\hline & $\geq 20$ & $115(52)$ \\
\hline \multirow{4}{*}{ Metastatic lymph nodes } & $1-6$ & $77(34.8)$ \\
\hline & $7-15$ & $65(29.4)$ \\
\hline & $\geq 16$ & $33(14.9)$ \\
\hline & 0 & $46(20.8)$ \\
\hline \multirow[t]{3}{*}{ Disease stage } & IIIa & $80(36)$ \\
\hline & IIIb & $84(38)$ \\
\hline & IV & $57(26)$ \\
\hline
\end{tabular}

More than two additional organ resections $(\mathrm{p}=0.001)$, erythrocyte transfusions of more than 2 units $(\mathrm{p}=0.001)$ and low total protein levels $(\mathrm{p}=0.008)$ were determined as the parameters that increase complication rates according to multivariate analysis. The parameters that increase mortality rates were as follows; having two or more additional organ resections $(\mathrm{p}=0.001)$, cardiovascular and respiratory comorbidities $(\mathrm{p}=0.002)$ and total gastrectomy $(\mathrm{p}=0.028)$. Finally, the parameters that increase enterocutaneus fistulas were erythrocyte transfusions $(\mathrm{p}=0.007)$ and more than one additional organ resections $(\mathrm{p}=0.002)$.

\section{Discussion}

The aim of gastric surgery is the removal all tumor tissue including microscopic foci since the roles of adjuvant radiotherapy and chemotherapy in gastric cancer are debatable. Total or distal gastrectomy should be performed depending on the tumor localization. Furthermore, adjacent tissues should also be removed if they are invaded by tumor. Both morbidity and mortality rates are decreased in parallel to the improvements in anesthesia and intensive care units (5).

Survival benefit of total gastrectomy for distal tumors could not be demonstrated with prospective randomized trials $(6,7)$. Besides the studies suggesting that total gastrectomy does not affect mortality and morbidity. Some other studies suggest just the opposite of this occurrence $(8,9)$. Irrespective 
of tumor localization, total gastrectomy rates of locally advanced tumors are high. In this study, although the incidence of proximally located and diffuse tumor type is $36 \%$, total gastrectomy rate is $62 \%$. Mortality rates of our patients were $8(6.4 \%)$ patients for total gastrectomy and 2 (2\%) patients for distal gastrectomy, whereas morbidity rates were 33 (26.6\%) patients for total gastrectomy and 15 (15\%) patients for distal gastrectomy. We found that total gastrectomy increased mortality rate according to multivariate analysis. We consider that this result may be related to the extensive operation field and pulmonary complications that might be triggered by extensive operations that were performed near the diaphragm. Pulmonary complication rates were $16 \%$ for total gastrectomy and $4 \%$ for subtotal gastrectomy (Table 3).

Higher lymphatic dissemination rates in gastric cancer lead to discussion on the borders of lymphatic dissection. It was reported that extended dissection may increase overall survival. However, other prospective randomized trials did not support this finding. In Western trials, D2 dissection seems to have higher mortality and morbidity than D1 dissection with similar survival rates (10-12).

D2 dissection should be applied for real staging according to Will-Rogers phenomenon, although it is difficult to evaluate the effect of D2 dissection on survival. It is better to dissect at least 15 lymph nodes for staging according to AJCC staging system, however this translates to more than D1 dissection. In our series, the average number of lymph nodes retrieved in D2 dissection was 30 . The dissection should not increase mortality and morbidity rates, because the effect of extended dissection on survival is controversial.

In our series, D2 dissection was only applied to $2 / 3$ of the patients. This rate is lower than $\mathrm{D} 2$ dissection rates applied to the patients with earlier stages. The fear of further raise of morbidity rates in patients with locally advanced disease may explain these low rates. In a series of 56 patients with locally advanced disease by Ozer et al. D1 dissection rate was reported to be $28.6 \%$ (13). But, the results of this study show the irrelevance of this concern. In our study, morbidity rates for D1 and D2 dissection groups were 18 (24.3\%) patients and
$30(20 \%)$, patients respectively, whereas mortality rates were four $(5.4 \%)$ patients for D1 group and 6 (4.1\%) patients for D2 group. We consider that D2 dissection can be administered safely, although procedures such as total gastrectomy and additional visceral resections are mostly applied with D2 dissection, which has similar mortality and morbidity rates with $\mathrm{D} 1$ dissection.

$\mathrm{R} 0$ resection is the most important factor for long-term survival of the patients with locally advanced gastric cancer (14-16). Furthermore, there are many studies stating that additional organ resections increase the morbidity and mortality rates (17-19).

Pancreatico-splenectomy is one of the morbid procedures with mortality rate of $\% 5$ 16 (20). Lo et al. suggested that total gastrectomy and pancreatico-splenectomy should be performed by experienced surgeons (21). The number of resected additional visceral organ is another factor on morbidity and mortality. Martin et al. determined that the rate of complications in gastrectomy group was $28 \%$ while it was $38 \%$ in splenectomy group and $51 \%$ in distal pancreatectomy group (14). In Nanthakumaran's trial, the mortality rates were $9.2 \%$ for the patients who had only gastrectomy and $18.3 \%$ for the others who had splenectomy. However, mortality rates of the patients with pancreatico-splenectomy were $23.3 \%$ and the others with additional liver resections were $40 \%$ (9). All adjacent organ adhesions that were suspicious for malignant infiltration were considered to be malignant and included to the specimen with clear surgical resection margins.

In this way, 38 to $56 \%$ of the patients with additional organ resection were seen pathologically to be in T4 stage $(22,23)$. In our series, 61 of 110 patients (55\%) with additional organ resection were seen pathologically to be in T4 stage. In our study, the mortality rates were $1.8 \%(\mathrm{n}: 2)$ for the patients who had not any additional organ resections and $3.75 \%$ $(n: 3)$ for the others who had only one organ resection. However, the morbidity rates were $13.5 \%$ (n:15) for the first group and 22,5\% $(\mathrm{n}: 18)$ for the others $(\mathrm{p}=0.161)$. Morbidity and mortality rates were $50 \%$ (n:15) and $16.6 \%$ $(n: 5)$ respectively in the group who had two or more additional organ resections and these rates were significantly higher $(\mathrm{p}=0.001)$. Splenectomy and distal pancreatectomy were 
the most common procedures in this group. Two or more additional organ resections were determined as a factor that increases mortality, morbidity and anastomotic dehiscence in multivariate analysis. In a study by Ozer et al., more than two additional organ resections are also related to morbidity (13).

Splenectomy was added to the primary procedures of 87 patients. Only 9 of the splenectomies were performed for iatrogenic injuries. The other reasons for splenectomies were direct tumoral invasion, tumoral implantations on splenic capsule and lymph node involvement in splenic hilus.

In the last few years, the results of different neo-adjuvant chemotherapy regimes given to the patients with radiologically proven invasion to the adjacent structures have been published in the literature. In a series by Wang et al., 87 patients with T4 tumor treated with neoadjuvant chemotherapy and operated with $89.7 \%$ R0 resection rate without any need for adjacent organ resection (24). In a series of 49 patients by Ott et al., this rate was 76\% (25). Seventeen of 18 patients presented by Newman (26) and 19 of 22 patients presented by Guo (27) could have been operated with R0 resection without requiring adjacent organ resection. In none of these studies, neoadjuvant chemotherapy demonstrated to increase operative morbidity and mortality. In our series of locally advanced tumors, not treated with neo-adjuvant chemotherapy, additional organ resection had to be applied in 50\% of the cases. At the same time our $\mathrm{R} 1$ and $\mathrm{R} 2$ resection rates are also high (13\% and 5\%). In literature, there are some other studies stating that $\mathrm{R} 0$ resection rates of locally advanced gastric tumors, not treated with neo-adjuvant chemotherapy, are low (28). But now, there is increasing evidence that neo-adjuvant chemotherapy potentially down-stages the tumor and therefore may improve the resectability rate with negative surgical margins $(29,30)$.

In literature, the morbidity and mortality rates for locally advanced gastric cancer surgery changes between $25-30 \%$ and $5-10 \%$ respectively $(31,32)$. The mortality rate for earlier stages of gastric cancer is $2-3 \%$ (13). Similarly, neo-adjuvant treatment may decrease morbidity and mortality rates by decreasing the need for additional organ resection (16).
Patient characteristics can effect mortality and morbidity rates besides the surgical procedures. Advanced age, male sex, blood loss during operation, low total protein and hemoglobin levels and duration of operation were determined as a factors which effect the morbidity rates negatively (33-36). Age, hemoglobin and lymphocyte counts were not found as significant factors for the morbidity in our series. In multivariate analysis, low total protein levels and blood transfusions of more than 2 units were significant factors for the morbidity, whereas cardiac and respiratory comorbidities were significant for the mortality. Low total protein levels and increased blood transfusion necessity lead to immunosuppression and problems in wound healing. Blood transfusions increase intracellular adhesion molecules and this may be the reason for high predisposition to infective complications. In patients with locally advanced gastric cancers, the need for blood transfusion either preoperatively or postoperatively was also high. Cardiac and respiratory problems are the most important causes of early mortality in upper abdominal surgery.

\section{Conclusion}

Additional organ resection rates of the patient with locally advanced gastric cancers that not given neo-adjuvant treatment is high and this occurrence increases the morbidity and mortality rates. While total gastrectomy was preferred surgical option for locally advanced gastric cancers, D2 dissection was used less frequently in this series of patients.

If the subtotal gastrectomy is the suitable procedure according to the tumor localization, surgeon should not insist on performing total gastrectomy. D2 dissection is a safe procedure in the treatment of locally advanced gastric carcinoma. Gastric cancer patients who have cardiac and respiratory comorbidities must be prepared to surgery carefully. Immunity and nutritional levels of the patients must be evaluated preoperatively.

Conflict of Interest: None.

\section{Kaynaklar}


1. Jemal A, Thomas A, Murray T, Thun M. Cancer statistics, 2002. CA Cancer J Clin 2002;52:23-47

2. Roder JD, Böttcher $\mathrm{K}$, Busch $\mathrm{R}$, Wittekind $\mathrm{C}$, Hermanek P, Siewert JR. Classification of regional lymph node metastases from gastric carcinoma. Cancer 1998;82:621-31

3. Winn RJ, Mc Clure J. The NCCN clinical practice guidelines in oncology. Gastric cancer. In: Journal of the National Comprehensive Cancer Network 2003;1:28-9

4. D'Ugo D, Persiani R, Zoccali M, et al. Surgical issues after neoadjuvant treatment for gastric cancer. Eur Rev Med Pharmacol Sci 2010;14:315-9

5. Macintyre IM, Akoh JA. Improving survival in gastric cancer: Review of operative mortality in English language publications from 1970. Br J Surg 1991;78:771-6

6. Gouzi JL, Huguier M, Fagniez PL, t al. Total versus subtotal gastrectomy for adenocarcinoma of the gastric antrum. A French prospective controlled study. Ann Surg 1989;209:162-6

7. Bozzetti F, Marubini E, Bonfanti G, Miceli R, Piano C, Gennari L. Subtotal versus total gastrectomy for gastric cancer. Five year survival rates in a multicenter randomized Italian trial. Ann Surg 1999;230:170-8

8. Onate-Ocana LF, Cortes-Cardinas SA, AielloCrocifoglio V, Mondragon-Sanchez R, Ruiz-Molina JM. Preoperative multivariate prediction of morbidity after gastrectomy for adenocarcinoma. Ann Surg Oncol 2000;7:281-8

9. Nanthakumaran S, Fernandes E, Thompson AM, Rapson T, Gilbert FJ, Park KG. Morbidity and mortality rates following gastric cancer surgery and contiguous organ removal, a population based study. Eur J Surg Oncol 2005;31:1141-4

10. Bonenkamp JJ, Hermans J, Sasako M, et al. Extended lymph node dissection for gastric cancer. N Engl J Med 1999;340:908-14

11. Cuschieri A, Fayers P, Fielding J, et al. Postoperative morbidity and mortality after D1 and D2 resections for gastric cancer: preliminary results of the MRC randomised controlled surgical trial. Lancet 1996;347:995-9

12. Cuschieri A, Weeden S, Fielding J et al. Patients survival after D1 and D2 resection for gastric cancer: long term results of the MRC randomised surgical trial. Br J Cancer 1999;79:1522-30

13. Ozer I, Bostanci EB, Orug T, Ozogul YB, Ulas M. Surgical outcomes and survival after multiorgan resection for locally advanced gastric cancer. Am J Surg. 2009;198:25-30

14. Martin RC 2nd, Jaques DP, Brennan MF, Karpeh M. Achieving RO resection for locally advanced gastric cancer: is it worth the risk of multiorgan resection? J Am Coll Surg. 2002;194:568-77

15. Carboni F, Lepiane P, Santoro R, Lorusso R, Mancini $\mathrm{P}$, Sperduti I. Extended multiorgan resection for T4 gastric carcinoma: 25-year experience. J Surg Oncol 2005;90:95-100

16. Lordick F, Siewert JR. Recent advances in multimodal treatment for gastric cancer: a review. Gastric Cancer 2005;8:78-85

17. Kodama I, Takamiya H, Mizutani K, Ohta J, Aoyagi K, Kofuji K. Gastrectomy with combined resection of other organs for carcinoma of the stomach with invasion to adjacent organs: clinical efficacy in a retrospective study. J Am Coll Surg 1997;184:16-22

18. Dhar DK, Kubota H, Tachibana M, Kinugasa S, Masunaga R, Shibakita M. Prognosis of T4 gastric carcinoma patients: an appraisal of aggressive surgical treatment. J Surg Oncol 2001;76:278-82

19. Martin RC 2nd, Jaques DP, Brennan MF, Karpeh M. Extended local resection for advanced gastric cancer: increased survival versus increased morbidity. Ann Surg 2002;236:159-65

20. Kitamura K, Nishida S, Ichikawa D et al. No survival benefit from combined pancreaticosplenectomy and total gastrectomy for gastric cancer. $\mathrm{Br} \mathrm{J}$ Surg 1999;86:119-22

21. Lo SS, Wu CW, Shen KH, Hsieh MC, Lui WY. Higher morbidity and mortality after combined total gastrectomy and pancreaticosplenectomy for gastric cancer. World J Surg 2002;26:678-82

22. Isozaki $\mathrm{H}$, Tanaka $\mathrm{N}$, Tanigawa $\mathrm{N}$, Okajima K. Prognostic factors in patients with advanced gastric cancer with macroscopic invasion to adjacent organs treated with radical surgery. Gastric Cancer 2000;3:202-10

23. Colen KL, Marcus SG, Newman E, Berman RS, Yee H, Hiotis SP. Multiorgan resection for gastric cancer: intraoperative and computed tomography assessment of locally advanced disease is inaccurate. J Gastrointest Surg 2004;8:899-902

24. Wang LB, Shen JG, Xu CY. Neoadjuvant chemotherapy versus surgery alone for locally advanced gastric cancer: a retrospective comparative study. Hepatogastroenterology 2008;55:1895-8

25. Ott K, Sendler A, Becker K, et al. Neoadjuvant chemotherapy with cisplatin, 5-FU, and leucovorin (PLF) in locally advanced gastric cancer: a prospective phase II study. Gastric Cancer 2003;6:159-67

26. Newman E, Marcus SG, Potmesil M, et al. Neoadjuvant chemotherapy with CPT-11 and cisplatin downstages locally advanced gastric cancer. J Gastrointest Surg 2002;6:212-23

27. Guo MG, Zheng Q, Cheng Z, Wang Y, Feng CN, Yang Z. The combination of docetaxel and cisplatin plus fluorouracil as neoadjuvant chemotherapy in the treatment of T4 stage gastric cancer. Surg Oncol 2010;19:1-3

28. Kim JH, Jang YJ, Park SS, et al. Surgical outcomes and prognostic factors for T4 gastric cancers. Asian J Surg 2009;32:198-204

29. Cunningham D, Allum WH, Stenning SP, Thompson JN, Van de Velde CJ, Nicolson M. Perioperative chemotherapy versus surgery alone for resectable gastroesophageal cancer. N Engl J Med 2006;355:1120

30. Mezhir JJ, Tang LH, Coit DG. Neoadjuvant therapy of locally advanced gastric cancer. J Surg Oncol 2010;101:305-14

31. Bloechle C, Izbicki JR, Limmer J, Kühn R, Hosch SB, Busch C. Multi-visceral resection for locally advanced gastric cancer. Acta Chir Belg 1995;95:725

32. Shchepotin IB, Chorny VA, Nauta RJ, Shabahang M, Buras RR, Evans SR. Extended surgical resection in T4 gastric cancer. Am J Surg 1998;175:123-6

33. Viste A, Haugstvedt T, Eide GE, Soreide O. Postoperative complications and mortality after surgery for gastric cancer. Ann Surg 1988;207:7-13 
34. Hartgrink $\mathrm{HH}$, van de Velde CJ, Putter $\mathrm{H}$, et al. Extended lymph node dissection for gastric cancer: who may benefit? Final results of randomized Dutch Gastric Cancer Group Trial. J Clin Oncol 2004;22:2069-77

35. Kodera Y, Sasako M, Yamamato S, Sano T, Nashimoto A, Kurita A. Identification of risk factors for the development of complications following extended and superextended lymphadenectomies for gastric cancer. Br J Surg 2005;92:1103-9

36. Ichikawa D, Kurioka $\mathrm{H}$, Yamaguchi $\mathrm{T}$, et al. Postoperative complications following gsatrectomy for gastric cancer during the last decade. Hepatogastroenterology 2004;51:613-7 